\title{
$\begin{array}{lllllllllllllllllll}\mathbf{K} & \mathbf{O} & \mathbf{S} & \mathbf{C} & \mathbf{I} & \mathbf{E} & \mathbf{L} & \mathbf{N} & \mathbf{E} & \mathbf{P} & \mathbf{R} & \mathbf{A} & \mathbf{W} & \mathbf{O} & \mathbf{K} & \mathbf{A} & \mathbf{R} & \mathbf{N} & \mathbf{E}\end{array}$
}

KOŚCIÓŁ I PRAWO 8(21) 2019, nr 1, s. 187-202

DOI: http://dx.doi.org/10.18290/kip.2019.8.1-12

\author{
Agnieszka Smoluchowska
}

\section{OBOSTRZENIE WYMIARU KARY \\ W PRAWIE KANONICZNYM \\ ORAZ POLSKIM PRAWIE KARNYM}

Ustawodawca w kan. 1326 § 1 i 2 Kodeksu Prawa Kanonicznego z 1983 r. ${ }^{1}$ zawarł okoliczności, które fakultatywnie mogą skutkować surowszym ukaraniem przestępcy. Należą do nich: 1) recydywa, 2) godność sprawcy lub nadużycie autorytetu lub urzędu, 3) pominięcie rozsądnego środka ostrożności, by zapobiec przestępstwu zawinionemu nieumyślnie. W sytuacji, w której wystąpią powyższe okoliczności, sędzia może skazać łamiącego prawo w sposób bardziej surowy [Renken 2015, 89-90]. Podobnie jak w systemie prawa kanonicznego, również ustawa Kodeks karny ${ }^{2}$ przewiduje sytuacje zaostrzające wymiar kary wobec sprawcy, tj.: 1) powrót do przestępstwa - recydywa podstawowa i multirecydywa (art. 64 $\S 1$ i 2), 2) sprawca uczynił sobie z popełnienia przestępstwa stałe źródło

MGR LIC. AgNiesZKa SMoluchowsKA - doktorant, Katedra Kościelnego Prawa Publicznego i Konstytucyjnego, Instytut Prawa Kanonicznego, Wydział Prawa, Prawa Kanonicznego i Administracji Katolickiego Uniwersytetu Lubelskiego Jana Pawła II; adres do korespondencji: Al. Racławickie 14, 20-950 Lublin, Polska; e-mail: agnisia 5@op.pl; https://orcid.org/0000-0003-0540-1439

${ }^{1}$ Codex Iuris Canonici auctoritate Ioannis Pauli PP. II promulgatus (25.01.1983), AAS 75 (1983), pars II, s. 1-317; tekst polski w: Kodeks Prawa Kanonicznego, przekład polski zatwierdzony przez Konferencję Episkopatu, Pallottinum, Poznań 1984 [dalej cyt.: KPK/83].

${ }^{2}$ Ustawa z dnia 6 czerwca 1997 r. Kodeks karny, Dz. U. z 2018 r., poz. 1600 z późn. zm. [dalej cyt.: k.k.]. 
dochodu (art. $65 \S 1$ ), 3) występek o charakterze chuligańskim (art. 57a § 1 i 2), 4) ciąg przestępstw (art. $91 \S 1,2$ i 3), 5) przestępstwo popełnione w zorganizowanej grupie lub związku mającym na celu popełnienie przestępstwa (art. $65 \S 1$ i 2), 6) przestępstwo o charakterze terrorystycznym (art. 115 $\S 20$ ). Inaczej jednak niż ustawodawca kościelny, ustawodawca świecki nie daje sędziemu możliwości wyboru, a nakłada na niego obowiązek zaostrzenia wymierzonej kary w przypadku powrotu do przestępstwa lub podniesienia granicy odpowiedzialności karnej w pozostałych sytuacjach.

W związku z powyższym prawo kanoniczne i świeckie zawierają systematyczne uregulowania zarówno o zbliżonym, jak i różnicującym charakterze. Systemy te nie funkcjonują jednak w próżni. Odnoszą się do konkretnych podmiotów - osób, które są jednocześnie wiernymi Kościoła katolickiego i obywatelami Rzeczypospolitej Polskiej. Niniejszy artykuł ma na celu wykazanie korelacji pomiędzy tymi porządkami prawnymi. Zasadniczym problemem jest obostrzenie wymiaru kary $\mathrm{w}$ prawie kanonicznym oraz polskim. Ponadto celem opracowania jest odpowiedź na pytanie, czy wyżej wymienione instytucje zawarte w systemie prawa kanonicznego i świeckiego wzajemnie ze sobą korespondują, czy też są względem siebie zupełnie przeciwstawne.

\section{RECYDYWA WEDŁUG PRAWA KANONICZNEGO I ŚWIECKIEGO}

Recydywa w ujęciu kanonicznego prawa karnego oznacza ponowne popełnienie przestępstwa przez tę samą osobę. Jest to niepokojące i niepożądane zjawisko społeczne. Wskazuje, że dotychczasowa przestroga udzielona sprawcy $\mathrm{w}$ formie skazania okazała się nieskuteczna, ponieważ nie spełniła nadziei pokładanych w prewencji szczególnej. W konsekwencji powrót do przestępstwa daje możliwość nadzwyczajnego zaostrzenia wymiaru kary [Syryjczyk 2005, 151-52].

Aby można było przyjąć, że osoba popełniająca przestępstwo działała w warunkach powrotu do przestępstwa, muszą być spełnione łącznie określone warunki: 1) sprawca popełnia kolejne przestępstwo, 2) po uprzednim skazaniu lub deklaracji kary latae sententiae (wymierzenie kary może mieć miejsce w wyniku drogi sądowej dekretem administracyjnym poprzez wyrok lub na drodze administracyjnej), 3) konieczne jest stwierdzenie, że sprawca trwa w złej woli [Wójcik, Krukowski, i Lempa 1987, 145-46]. 
W nauce prawa kanonicznego brak jest jednomyślności, do jakiej kategorii zalicza się ponowne przestępstwo. Mianowicie, czy może być to „każde”, czy też „kolejne” ${ }^{3}$. Z analizy cytowanego wyżej kanonu wynika, że recydywa obejmuje przestępstwa podobne, jak i zupełnie innego rodzaju niż dotychczas dokonane [Syryjczyk 2008, 168] .

Należy podkreślić, że nie zawsze popełnienie nowego przestępstwa, nawet podobnego, oznacza powrót do przestępstwa zgodnie z literą prawa kanonicznego. Konieczne jest bowiem ustalenie okoliczności, w jakich zostało ono popełnione oraz czasu, który upłynął od poprzedniego skazania. $\mathrm{Z}$ uwagi na to, że w prawie kanonicznym nie występuje instytucja przedawnienia recydywy czy też zatarcia skazania, upływ czasu jest nielimitowany. Zasadą jest jednak, że im krótszy upływ czasu od uprzedniego skazania, tym trwanie w złej woli jest większe. Trwanie w tym stanie wskazuje na złą wolę sprawcy, a tym samym recydywa oznacza jego zły zamiar i to w formie zwiększonej. Nowe przestępstwo nie może zatem być popełnione $\mathrm{z}$ winy nieumyślnej. Natomiast wcześniejsze skazanie może dotyczyć przestępstwa popełnionego nieumyślnie [tamże, 169-70]. Należy przy tym uwzględnić liczbę ponownie popełnionych przestępstw. Większa liczba popełnionych przestępstw po skazaniu może przemawiać za większą poczytalnością sprawcy, a także uporem w złej woli [Syryjczyk 2005, 161]. Prawodawca kościelny powierzył ustalenie wyżej cytowanych okoliczności sędziemu. W przypadku gdyby sędzia stwierdził, że nie można przypisać sprawcy powrotu do przestępstwa, nie może on przy wymierzaniu kary zaostrzyć jej wymiaru. Zaistniałą sytuację należy bowiem traktować jako nowe przestępstwo, niezwiązane z dotychczasowym skazaniem [tamże, 170].

Instytucja recydywy funkcjonuje również w prawie świeckim. Oznacza ona powrót do przestępstwa (od łac. recedere - ponownie wpadać) [Królikowski i Zawłocki 2010, 381]. Współcześnie w literaturze przedmiotu powrót do przestępstwa jest ujmowany wieloaspektowo. Możemy wyróżnić pojęcie recydywy kryminologicznej (każdy rzeczywisty powrót do przestępstwa), jurydycznej (powrót do przestępstwa, z którym przepisy ustawy karnej łączą

${ }^{3}$ J. Arias uważa, że do recydywy dochodzi wówczas, gdy sprawca popełnia kolejne przestępstwo tego samego rodzaju, co poprzednie, za które został prawomocnie skazany [Arias 2011, 998]. Inny pogląd reprezentuje J. Syryjczyk. Według niego ścisła interpretacja kan. $1326 \S 1,1^{\circ} \mathrm{w}$ żadnym razie nie daje podstaw do tego typu wniosków. Gdyby ustawodawca uznał, że kolejne popełnione przestępstwo musi należeć do kategorii podobnych, zawarłby taki wymóg w dyspozycji kanonu. Taka sytuacja miała bowiem miejsce w Kodeksie Prawa Kanonicznego z 1917 r. [Syryjczyk 2008, 168-69]. 
określone ujemne następstwa dla sprawcy) i penitencjarnej (powrót do przestępstwa, którego konsekwencją jest ponowne odbywanie kary pozbawienia wolności) [Zoll 2012, 878]. W ramach recydywy w znaczeniu jurydycznym wyróżnia się recydywę ogólną i specjalną. Recydywa ogólna obejmuje wypadki popełnienia jakiegokolwiek przestępstwa przez osobę uprzednio karaną za przestępstwa umyślne. W obrębie recydywy specjalnej wyróżnia się recydywę specjalną podstawową (zwykłą, prostą), której przesłanki określa art. $64 \S 1$ k.k. oraz recydywę specjalną wielokrotną (multirecydywę), której przesłanki normuje art. $64 \S 2$ k.k. [tamże, 879].

Nie sposób w tym miejscu pominąć pierwszej różnicy pomiędzy systemem prawa kanonicznego a świeckiego. W prawie kanonicznym brak jest podziału recydywy, fakt popełnienia kilku następnych przestępstw świadczy o większym natężeniu złej woli i uporze. Recydywa ogólna w Kodeksie karnym oznacza powrót do jakiegokolwiek przestępstwa, który sąd uwzględnia przy wymiarze kary z uwagi na dotychczasowy sposób życia (art. 53 § 2) jako okoliczność wpływającą na zaostrzenie kary. Skutkiem powrotu do przestępstwa po uprzednim skazaniu za jakiekolwiek przestępstwo umyślne jest brak możliwości stosowania instytucji warunkowego umorzenia postępowania (art. 66 § 1) [Grześkowiak i Wiak 2017, 460].

W systemie świeckim recydywa szczególna podstawowa zachodzi wtedy, gdy zostaną spełnione następujące przesłanki wymienione w art. $64 \S 1$ k.k.: 1) skazanie za poprzednie umyślne przestępstwo na karę pozbawienia wolności, 2) odbycie co najmniej 6 miesięcy kary pozbawienia wolności, 3) popełnienie nowego przestępstwa przed upływem 5 lat od zakończenia odbywania poprzedniej kary, 4) nowe przestępstwo musi być umyślne i podobne do tego, za które sprawca był poprzednio skazany [Bojarski 2017, 456].

Przestępstwo umyślne określa art. $9 \S 1$ k.k. Poza tym za przestępstwo umyślne z punktu widzenia zasad wymiaru kary należy również uznać przestępstwo z winy „kombinowanej”. Decyduje o tym umyślność czynu wyjściowego, np. umyślne uszkodzenie ciała, z którego wynikła objęta nieumyślnością śmierć. Nieumyślność dołączająca się do umyślności nie może powodować łagodniejszej oceny danego czynu niż sama tylko umyślność charakteryzująca czyn [Bojarski 2013, 190]. Jest to kolejna różnica systemów prawnych. Prawo karne kanoniczne dla zaistnienia recydywy nie wymaga, aby kolejne przestępstwo zostało popełnione $\mathrm{z}$ winy umyślnej.

Samo określenie, co oznacza w rzeczywistości odbycie kary 6 miesięcy, jest pojęciem złożonym. Art. $64 \S 1$ k.k. nie wprowadza wymagania, aby 
skazanie za pierwsze przestępstwo było skazaniem na karę pozbawienia wolności bez warunkowego zawieszenia jej wykonania. Układ recydywy specjalnej podstawowej nie wyłącza sam przez się wykonania kary pozbawienia wolności orzeczonej za przestępstwo uprzednie, która pierwotnie była warunkowo zawieszona i sprawca odbył ją w wymiarze co najmniej 6 miesięcy dopiero na skutek zarządzenia sądu wydanego na podstawie art. 75 k.k. Podstawę recydywy specjalnej podstawowej może stanowić odbycie kary pozbawienia wolności orzeczonej za uprzednie przestępstwo nie tylko w całości, lecz także w części, jeżeli sprawca odcierpiał faktycznie co najmniej 6 miesięcy kary [tamże, 238].

Należy przy tym pamiętać, że sześciomiesięczny okres odbywania kary może wynikać z sumy czasu spędzonego w zakładzie karnym (przerywanego przepustkami bądź przerwami w odbywaniu kary). Zgodnie z orzecznictwem Sądu Najwyższego, nie ma także znaczenia, czy sprawca odbywał karę na terenie Rzeczypospolitej Polskiej, czy też poza jej granicami ${ }^{4}$. Czyn, za który sprawca odbywał karę zagranicą, musi być przestępstwem w ocenie polskiego porządku prawnego, oraz przestępstwem w kraju, gdzie sprawca odbywał karę (warunek podwójnej karalności) [Giezek 2012, 456].

Okres pięcioletni, o którym mowa w art. $64 \S 1$ k.k., należy liczyć od zakończenia odbywania kary pozbawienia wolności. W sytuacji, w której kara pozbawienia wolności orzeczona za przestępstwo podobne do nowego została połączona $\mathrm{z}$ inną karą węzłem kary łącznej, okres pięcioletni biegnie od odbycia w całości lub części kary łącznej [Zoll 2012, 892].

Analizowane wyżej przesłanki dotyczące wymiaru kary oraz czasu, w którym musi być popełnione kolejne przestępstwo, aby przyjąć recydywę, stanowi kolejną różnicę pomiędzy systemem kanonicznego prawa karnego a systemem świeckim. Ustawodawca kościelny nie przewiduje zatarcia skazania, zatem nie określa też żadnego z wyżej wskazanych terminów.

Ostatnią przesłanką niezbędną do zaistnienia recydywy opisanej w art. $64 \S 1$ k.k. jest wymóg, by nowe przestępstwo było podobne do tego, za które sprawca był poprzednio skazany. Podobieństwo przestępstw zostało oparte (art. $115 \S 3$ ) na trzech kryteriach. Przestępstwami podobnymi są przestępstwa należące do tego samego rodzaju. Są nimi również przestępstwa $\mathrm{z}$ zastosowaniem przemocy lub groźby jej użycia (kryterium sposobu

${ }^{4}$ Uchwała Sądu Najwyższego z dnia 24 kwietnia 1975 r., sygn. akt VI KZP 59/74, OSNKW 1975, nr 6, poz. 71. 
działania sprawcy). Przestępstwami podobnymi są także przestępstwa popełnione w celu osiągnięcia korzyści majątkowej (kryterium podmiotowe) [Bojarski 2013, 190].

Konsekwencją stwierdzenia, że sprawca działał w warunkach recydywy specjalnej zwykłej jest możliwość wymierzenia kary przewidzianej za dane przestępstwo w wysokości do górnej granicy ustawowego zagrożenia zwiększonego o połowę. Przepisy dotyczące powrotu do przestępstwa stanowią lex specialis $\mathrm{w}$ stosunku do art. $53 \mathrm{k} . \mathrm{k}$.

Zgodnie z art. $64 \S 2$ k.k. recydywa wielokrotna zachodzi, gdy: 1) sprawca był już uprzednio skazany w warunkach recydywy podstawowej (był już co najmniej dwukrotnie skazany), 2) łącznie odbył co najmniej rok kary pozbawienia wolności, 3) nowe przestępstwo popełnił przed upływem 5 lat po odbyciu ostatniej kary (w całości lub części), 4) nowe przestępstwo jest umyślne, 5) sprawca ponownie popełnia przestępstwo, które skierowane jest przeciwko życiu lub zdrowiu bądź stanowi przestępstwo zgwałcenia, rozboju, kradzieży z włamaniem lub inne przestępstwo przeciwko mieniu popełnione z użyciem przemocy lub groźby jej użycia [Bojarski 2017, 458].

Ustawowy status recydywisty wielokrotnego sprawca może uzyskać przy trzecim skazaniu. Chodzi tu o przypadki recydywistów jednokrotnych, którzy po odbyciu łącznie co najmniej roku kary pozbawienia wolności popełniają w ciągu pięciu lat po odbyciu w całości lub części ostatniej kary pozbawienia wolności umyślne przestępstwo wymienione w katalogu [Bojarski 2013, 191]. Nie stwarza przesłanek do przyjęcia multirecydywy popełnienie przez sprawcę skazanego uprzednio w warunkach określonych $\mathrm{w}$ art. $64 \S 1 \mathrm{k} . \mathrm{k}$. przestępstwa umyślnego niemieszczącego się w katalogu przestępstw wskazanych w art. $64 \S 2$ k.k., chociażby było ono podobne do przestępstw objętych układem recydywy specjalnej podstawowej, gdyż wyliczenie to jest wyczerpujące [Zoll 2012, 897].

Zasadniczą konsekwencją recydywy wielokrotnej jest nadzwyczajne obostrzenie kary, które ma trzy różne „wymiary”. Po pierwsze, sąd ma obowiązek wymierzyć multirecydywiście karę pozbawienia wolności, chociażby nawet dane przestępstwo było zagrożone karami nieizolacyjnymi. Po drugie, kara orzeczona musi być wyższa od dolnej granicy ustawowego zagrożenia związanego z przypisanym multirecydywiście przestępstwem. Po trzecie, tak jak w przypadku recydywy specjalnej podstawowej, multirecydywa stwarza podstawę do wymierzenia sprawcy kary wyższej od górnego progu ustawowego zagrożenia - w wymiarze aż do półtorakrotności 
tego progu [tamże, 900]. Z uwagi na przyjętą w Kodeksie karnym zasadę, że w wypadku każdej zbrodni górna granica ustawowego zagrożenia jest równa ustawowej górnej granicy kary pozbawienia wolności, określonej w art. 37 k.k. na lat 15, nadzwyczajnego obostrzenia kary, polegającego na podwyższeniu górnej granicy ustawowego zagrożenia nie stosuje się do zbrodni (art. 64 § 3 k.k.) [Grześkowiak i Wiak 2017, 461-62].

Analizowane systemy prawne zawierają instytucję recydywy. Trudno jest jednak porównywać powrót do przestępstwa ujęty w przepisach $K o$ deksu karnego do opisanego $\mathrm{w}$ prawie kanonicznym. Jest to wynikiem celu, jaki ta instytucja ma osiągnąć w każdym z systemów prawa. W prawie kanonicznym przyjęcie recydywy służy ocenie sprawcy, czy nadal pozostaje w złej woli i ewentualnemu wpłynięciu na niego, aby zaprzestał trwania $\mathrm{w}$ uporze. Tymczasem $\mathrm{w}$ prawie świeckim sąd na podstawie określonych przesłanek obligatoryjnie przypisuje sprawcy działanie w warunkach powrotu do przestępstwa.

\section{GODNOŚĆ OSOBY POPEŁNIAJĄCEJ PRZESTĘPSTWO}

Godność osoby popełniającej przestępstwo jest zagadnieniem uregulowanym na gruncie prawa kanonicznego. W znaczeniu prawnym należy interpretować ją jako szczególną cechę konkretnej osoby, która sprawi, że cieszy się ona większym poważaniem oraz zasługuje na większy szacunek pozostałych członków danej społeczności [Arias 2011, 998]. Przymiot ten nie oznacza jednak tylko uprawnienia. W myśl zasady „komu wiele dano, od tego wiele wymagać się będzie", w przypadku popełnienia czynu zabronionego przez tego typu osobę jej odpowiedzialność będzie większa niż przeciętnego człowieka [Syryjczyk 2008, 169-72]. Waga przestępstwa bowiem rośnie proporcjonalnie do stopnia godności. Należy przy tym pamiętać, że kan. $1326 \mathrm{KPK} / 83$ dotyczy jedynie sprawcy przestępstwa, nie zaś jego ofiary [Arias 2011, 998; Wójcik, Krukowski, i Lempa 1987, 146].

W systemie prawa świeckiego ustawodawca nie przewidział zróżnicowania odpowiedzialności z uwagi na zajmowane przez sprawcę stanowisko. Kwestia piastowanego urzędu lub przynależności do grupy społecznej może mieć jedynie wydźwięk moralny, nie ma natomiast nigdy bezpośredniego przełożenia na wymiar kary. Kwestia podmiotu popełniającego przestępstwo ma jedynie odzwierciedlenie w trakcie modyfikowania opisu czy- 
$\mathrm{nu}$ lub jest brana pod uwagę $\mathrm{w}$ trakcie stosowania przez sędziego dyrektyw wymiaru kary. Jedyna taka sytuacja to podział na przestępstwa podstawowe i kwalifikowane. Prawodawca kościelny „godność osoby” traktuje jako osobną instytucję, natomiast w polskim prawie karnym jest to znamię przestępstwa indywidualnego, nie zaś nadzwyczajne obostrzenie kary.

\section{NADUŻYCIE WŁADZY LUB URZĘDU W CELU POPEŁNIENIA PRZESTĘPSTWA}

Nadużycie władzy lub urzędu w celu popełnienia przestępstwa jest kolejną z wymienionych w kan. $1326 \S 1,2^{\circ} \mathrm{KPK} / 83$ okoliczności, w przypadku której sędzia może wymierzyć sprawcy surowszą karę. Definicję urzędu zawiera kan. 145 § 1: „Urząd kościelny jest jakimkolwiek ustanowionym na stałe zadaniem z postanowienia czy to Bożego, czy kościelnego dla realizacji celu duchowego". Natomiast kan. $135 \S 1$ w określeniu władzy rządzenia zawiera: władzę ustawodawczą, wykonawczą i sądowniczą. W nauce prawa kanonicznego przyjęto, że celem jakiejkolwiek władzy czy urzędu jest służba w budowaniu sprawiedliwego porządku społecznego. Zatem posłużenie się władzą lub piastowanym urzędem $\mathrm{w}$ celu popełnienia czynu zabronionego jest szczególnie ciężkim przestępstwem, które przynosi publiczną szkodę mogącą wywoływać zgorszenie i pogardę dla władzy kościelnej [Gajda 2008, 38-39; Arias 2011, 998]. W sytuacji, w której zachodzi taki przypadek, ustawodawca traktuje go jako okoliczność zwiększającą poczytalność sprawcy. Wykazuje on bowiem szczególną przewrotność i złą wolę czynienia bezprawia. Tym samym może być podstawą do wymierzenia surowszej kary [Syryjczyk 2008, 175].

W prawie świeckim nadużycie władzy lub urzędu stanowi samodzielny typ przestępstwa zawarty w art. 231 k.k. Zakłada on odpowiedzialność funkcjonariusza $\mathrm{w}$ przypadku wypełnienia przez niego dodatkowych znamion ujętych w art. 231 k.k.: niedopełnieniem przez niego obowiązków lub przekroczeniem uprawnień jako strona przedmiotowa przestępstwa, a określonym skutkiem (przestępstwo materialne) na szkodę interesu publicznego lub prywatnego.

W przypadku dwóch wyżej analizowanych przestępstw ustawodawca kościelny i państwowy zauważył konieczność szczególnego napiętnowania nadużywania władzy poprzez możliwość zaostrzenia wymiaru kary, jeżeli 
tego typu czyn zostanie dowiedziony. W takich sytuacjach system prawa kanonicznego i świeckiego wzajemnie ze sobą korelują i uzupełniają się.

\section{WINA NIEUMYŚLNA ZBLIŻONA DO UMYŚLNEJ}

W kan. $1326 \S 1,3^{\circ} \mathrm{KPK} / 83$ ustawodawca kościelny zawarł ostatni przypadek, w którym możliwe jest wymierzenie surowszej kary. Culpa proxima dolo jest to najwyższy stopień winy nieumyślnej zbliżony do umyślności. Mamy z nim do czynienia, gdy sprawca przewidział możliwość popełnienia przestępstwa, jednak nie podjął żadnych środków, jakie przedsięwziąłby każdy staranny człowiek do jego uniknięcia [tamże, 176]. Zatem sytuacja ta nie polega na tym, że sprawca nie przewidział skutku swojego działania. Wręcz przeciwnie, zaniedbał środków ostrożności, do jakich uciekłaby się przeciętnie roztropna osoba, aby uniknąć negatywnych skutków. Prawodawca uznał, że tego rodzaju zawinione przestępstwo ma szczególną wagę [Arias 2011, 998]. Ponadto upoważnił on sędziego, aby w przypadku zaistnienia opisanej wyżej sytuacji, ukarał surowiej sprawcę niż przewiduje to ustawa lub nakaz. Ustawodawca używa przy tym słów fakultatywnych, pozostawiając ostatecznie decyzję sędziemu [Wójcik, Krukowski, i Lempa 1987, 147]. Mając na uwadze powyższe okoliczności, należy zaznaczyć, że od strony podmiotowej przestępstwa stopień zawinienia sprawcy jest większy niż w przypadku zwykłego niedbalstwa. Konsekwencją tego jest możliwość wymierzenia przez sędziego surowszej kary [Syryjczyk 2008, 176].

W systemie prawa świeckiego mamy do czynienia z zupełnie odmiennym ujęciem. Sytuacja zdefiniowana w prawie kanonicznym jako „wina nieumyślna zbliżona do umyślnej” $\mathrm{w}$ prawie świeckim przyjęta jest jako „lekkomyślność”, czyli forma nieumyślności. Jakkolwiek jest to okoliczność skutkująca najsurowszą odpowiedzialnością w przypadku winy nieumyślnej, jest ona łagodniejsza niż odpowiedzialność za ten sam czyn popełniony umyślnie. Instytucja nieumyślności, funkcjonująca w polskim prawie karnym, pozostaje poza zainteresowaniem niniejszej pracy, bowiem w żadnym zakresie nie wpływa na obostrzenie kary.

W dalszej części artykułu zostaną przeanalizowane instytucje prawa świeckiego, które z uwagi na swą specyfikę nie mają odpowiedników w systemie prawa kanonicznego. 


\section{UCZYNIENIE Z PRZESTĘPSTWA STAŁEGO ŹRÓDŁA DOCHODU, POPEŁNIENIE PRZESTEPSTWA W ZORGANIZOWANEJ GRUPIE LUB ZWIĄZKU MAJĄCYM NA CELU POPEŁNIENIE PRZESTĘPSTWA, PRZESTĘPSTWA O CHARAKTERZE TERRORYSTYCZNYM}

W związku z nasileniem się w ostatnich latach tzw. przestępczości zorganizowanej, ustawodawca zaostrzył wymiar kary, środków karnych oraz środków związanych z poddaniem sprawcy próbie, względem sprawcy, który z popełnienia przestępstw uczynił sobie stałe źródło dochodu (tzw. przestępca zawodowy) lub popełnił przestępstwo, działając w zorganizowanej grupie albo związku mającym na celu popełnianie przestępstw [Mozgawa 2013, 176]. Reguła ta została zawarta w art. $65 \S 1$ i 2 k.k. Przepis poleca stosowanie zasad wymiaru kary i innych środków przewidzianych dla recydywistów wielokrotnych, również przestępców zawodowych, uczestniczących w zorganizowanych grupach, a po zmianie przepisów przez ustawę z dnia 16 kwietnia 2004 r. - także wobec sprawców przestępstwa o charakterze terrorystycznym [Bojarski 2013, 193]. Za tym zrównaniem podąża przekonanie ustawodawcy co do wysokiego niebezpieczeństwa dla dóbr prawnych płynącego ze strony tych sprawców [Giezek 2012, 461]. Zastosowanie wobec wymienionych w przepisie kategorii sprawców obostrzenia kary przewidzianego dla multirecydywistów nie jest związane $\mathrm{z}$ uprzednim skazaniem za przestępstwo. Podstawą wyznaczenia surowych granic wymiaru kary jest ustalenie, że sprawca należy do jednej z wymienionych kategorii [Grześkowiak i Wiak 2017, 462].

Art. $65 \S 1$ k.k. zawiera przesłanki, których wystąpienie (jednak nie łączne) jest niezbędne do tego, aby możliwe było zaostrzenie wymiaru kary. Stałe źródło dochodu nie musi oznaczać wyłącznego źródła dochodu, lecz utrzymującego się $\mathrm{w}$ charakterze pewnego procederu. Nie ma przeszkód, aby osoba zatrudniona była objęta tym pojęciem, jeżeli niezależnie od zatrudnienia uprawia określony rodzaj przestępczości w innym czasie, np. zajmuje się paserstwem. Stały oznacza utrzymujący się przez dłuższy czas [Bojarski 2013, 193]. Uwagę zwraca użycie liczby pojedynczej w tym przepisie, co oznacza, że wystarcza, aby sprawca uczynił sobie stały dochód z popełnienia jednego przestępstwa określonej kategorii [Konarska-Wrzosek 2016, 393].

Zorganizowana grupa jest zgrupowaniem co najmniej trzech osób, charakteryzującym się na ogół niskim stopniem zorganizowania, którego celem jest 
popełnianie przestępstw. Niektóre elementy wewnętrznej organizacji polegają na podziale ról i koordynacji działania [Bojarski 2017, 461].

Związek mający na celu popełnianie przestępstwa różni się od zorganizowanej grupy utworzonej w tym samym celu wyższym stopniem zorganizowania: trwałą formą organizacyjną, wyłonionym kierownictwem, rygorami organizacyjnymi w sferze wypełniania poleceń „przełożonych” wraz z określonymi konsekwencjami w razie odmowy wykonania, a także ustalonymi zasadami członkostwa oraz sformalizowanym sposobem przyjmowania członków [Zoll 2012, 263-64].

Definicja przestępstwa o charakterze terrorystycznym została zawarta w art. $115 \S 20$ k.k. ${ }^{5}$ Ustawodawca przewidział, że przepis art. $65 \S 2$ k.k. ma również zastosowanie wobec sprawców przestępstwa z art. 258 k.k., za wyjątkiem zaostrzenia wymiaru kary.

\section{WYSTĘPEK O CHARAKTERZE CHULIGAŃSKIM}

Aby przestępstwo (a ściślej występek) miało charakter chuligański, musi być spełnionych łącznie kilka warunków: a) sprawca dopuścił się czynu polegającego na umyślnym zamachu na zdrowie, wolność, cześć lub nietykalność cielesną, na bezpieczeństwo powszechne, na działalność instytucji państwowych lub samorządu terytorialnego, na porządek publiczny albo na umyślnym niszczeniu, uszkodzeniu lub czynieniu niezdatną do użytku cudzej rzeczy; b) sprawca musi działać publicznie; c) sprawca musi działać bez powodu lub z oczywiście błahego powodu; d) sprawca poprzez swoje zachowanie okazywać rażące lekceważenie porządku prawnego [Mozgawa 2013, 287]. Ustawodawca zatem w sposób enumeratywny wskazał dobra chronione prawem, których naruszenie stanowi jedną z niezbędnych przesłanek, aby popełnionemu czynowi przypisać charakter chuligański. Kolejnym znamieniem chuligańskiego charakteru czynu jest umyślność działania sprawcy. Opisując następną przesłankę z art. 57a § 1 k.k., T. Bojarski

\footnotetext{
${ }^{5}$ Art. $115 \S 20$ k.k. stanowi: „Przestępstwem o charakterze terrorystycznym jest czyn zabroniony zagrożony karą pozbawienia wolności, której górna granica wynosi co najmniej 5 lat, popełniony w celu: 1) poważnego zastraszenia wielu osób, 2) zmuszenia organu władzy publicznej Rzeczypospolitej Polskiej lub innego państwa albo organu organizacji międzynarodowej do podjęcia lub zaniechania określonych czynności, 3) wywołania poważnych zakłóceń w ustroju lub gospodarce Rzeczypospolitej Polskiej, innego państwa lub organizacji międzynarodowej - a także groźba popełnienia takiego czynu”.
} 
podaje: „(...) sprawca musi działać publicznie, a więc w obecności innych osób, w szczególności w miejscu publicznym. Tak postępując, demonstruje on swoje nieposzanowanie dla chronionego systemu wartości. Czyn ma być popełniony bez powodu lub z oczywiście błahego powodu, co oznacza brak przyczyny, przesłanki demonstrowania postawy agresywnej. Końcowy element w określeniu chuligańskiego charakteru występku wskazuje na rażące lekceważenie porządku prawnego" [Bojarski 2013, 285].

W obowiązującym porządku prawnym nie istnieje zbrodnia o charakterze chuligańskim. W praktyce okoliczności tworzące typ występku chuligańskiego mogą jednak koegzystować ze znamionami zbrodni. W takiej sytuacji należy je traktować jako okoliczności obciążające, które wpływają na obostrzenie sankcji [Konarska-Wrzosek 2016, 393] ${ }^{6}$.

Konsekwencją ustalenia, że dany czyn stanowi występek o charakterze chuligańskim jest wymierzenie sprawcy surowszej kary. Nadzwyczajne obostrzenie określone $\mathrm{w}$ art. $57 \mathrm{a} \S 1 \mathrm{k} . \mathrm{k}$. polega na podniesieniu dolnej granicy ustawowego zagrożenia o połowę [Zoll 2012, 799]. Na podstawie $\S 2$ sąd zobowiązany jest do orzeczenia jednego spośród trzech środków karnych: nawiązki na rzecz pokrzywdzonego, obowiązku naprawienia szkody lub nawiązki na podstawie art. 46 k.k. Orzeczenie takie jest zależne od ustalenia pokrzywdzonego [Grześkowiak i Wiak 2017, 447].

Ustawodawca przewidział ponadto kilka innych sytuacji mających związek z instytucją nadzwyczajnego obostrzenia kary. I tak w art. 58 § 4 k.k. wprowadzono zakaz orzekania kary ograniczenia wolności albo grzywny zamiast kary pozbawienia wolności, w warunkach określonych w art. 59 § 2 k.k. - zakaz odstąpienia od wymierzania kary w warunkach określonych $\mathrm{w}$ art. $59 \S 1$ k.k., a ponadto dodano przepis (art. 69 § 4 k.k.) współokreślający przesłanki warunkowego zawieszenia kary [Giezek 2012, 747].

\section{CIĄG PRZESTĘPSTW}

Ostatnią okolicznością wpływającą na zaostrzenie kary w świeckim systemie prawnym jest ciąg przestępstw. Instytucja ta została zawarta w art. 91 k.k. i zachodzi, gdy łącznie zostały spełnione następujące przesłanki:

\footnotetext{
${ }^{6}$ Wyrok Sądu Najwyższego z dnia 15 września 1971 r., sygn. akt II KR 164/71, OSNKW 1972, nr 5, poz. 85.
} 
sprawca popełnia 1) w krótkich odstępach czasu, 2) z wykorzystaniem takiej samej sposobności, 3) dwa lub więcej przestępstw zanim zapadł pierwszy chociażby nieprawomocny wyrok.

Ciąg przestępstw zachodzi wówczas, jeżeli sprawca popełnia dwa lub więcej przestępstw nieprzedzielonych wyrokiem chociażby nieprawomocnym (tak jak przy karze łącznej), orzeka się jedną karę na podstawie przepisu, którego znamiona każde z tych przestępstw wyczerpuje [Bojarski 2013, 224].

Pojęcie „krótkie odstępy czasu” nie zostało „ściśle” zdefiniowane w przepisach Kodeksu karnego, natomiast wypracowane zostało w bogatym orzecznictwie i praktyce. Jedynym miejscem, w którym znajduje się konkretne określenie „krótkiego odstępu czasu” jako 6-ciu miesięcy, jest art. 6 § 2 ustawy Kodeks karny skarbowy?

Nowe ujęcie znamion ciągu przestępstw, polegające na wprowadzeniu do treści art. $91 \S 1$ k.k., pojęcia „tej samej sposobności” znacząco rozszerza możliwość zastosowania tej normy. Ta sama sposobność pozwala bowiem na przyjęcie popełnienia czynu ciągłego w oderwaniu od faktycznej kwalifikacji czynów popełnianych przez sprawcę. Ma to kolosalne znaczenie przy rozstrzyganiu spraw, w których sprawca popełnia przestępstwa choćby w formie stadialnej i zjawiskowej.

Konsekwencją ciągu przestępstw jest wymierzenie kary z nadzwyczajnym jej obostrzeniem w granicach do górnej granicy ustawowego zagrożenia przewidzianego $\mathrm{w}$ przepisie, którego znamiona każde $\mathrm{z}$ przestępstw wyczerpuje, zwiększonego o połowę. Wymierzona w ten sposób kara nie może oczywiście przekroczyć górnej granicy danego rodzaju kary (art. 38 § 2 k.k.). Zastosowanie znajduje także reguła określona w art. 38 § 1 k.k. [Filar 2012, 497].

\section{ZAKOŃCZENIE}

Instytucje nadzwyczajnego zaostrzenia kary uregulowane w KPK/83 i Kodeksie karnym nie są tożsame. Pomimo podobnych nazw określonych instytucji (np. recydywa) różnice pomiędzy nimi są wyraźne i widoczne. Te

\footnotetext{
${ }^{7}$ Ustawa z dnia 10 września 1999 r. Kodeks karny skarbowy, Dz. U. z 2018 r., poz. 1958 z późn. zm.
} 
dwa systemy prawne mają swe charakterystyczne, indywidualne i niepowtarzalne instytucje. Jest to związane z faktem, że polskie prawo karne i prawo kanoniczne opierają się na innych założeniach i służą innym celom. Prawo karne polskie jest prawem o wysokim stopniu abstrakcji, bowiem jest skierowane do wszystkich obywateli Rzeczypospolitej Polskiej, a także osób przebywających na jej terenie. Jego celem jest ukaranie sprawcy w sposób zgodny z oczekiwaniami społeczeństwa oraz prewencja generalna i ogólna. Prawo kanoniczne natomiast odnosi się do konkretnych podmiotów będących wiernymi Kościoła katolickiego. Ponadto kieruje się ono zasadą miłosierdzia kościelnego wymiaru kary zawartą w kan. 1349 KPK/83.

\section{PIŚMIENNICTWO}

Arias, Juan. 2011. „Komentarz do kan. 1326.” W Codex Iuris Canonici. Kodeks Prawa Kanonicznego. Komentarz. Powszechne i partykularne ustawodawstwo Kościoła katolickiego. Podstawowe akty polskiego prawa wyznaniowego. Edycja polska na podstawie wydania hiszpańskiego, red. Piotr Majer, 997-998. Kraków: Wolters Kluwer Polska.

Bojarski, Marek, red. 2017. Prawo karne materialne. Część ogólna i szczególna. Warszawa: Wolters Kluwer Polska.

Bojarski, Tadeusz, red. 2013. Kodeks karny. Komentarz. Warszawa: LexisNexis.

Filar, Marian, red. 2012. Kodeks karny. Komentarz. Warszawa: LexisNexis.

Gajda, Piotr M. 2008. Sankcje karne $w$ Kościele $w$ świetle Kodeksu Prawa Kanonicznego Jana Pawła II oraz późniejszych zmian i uzupełnień. Tarnów: Wydawnictwo Diecezji Tarnowskiej Biblos.

Giezek, Jacek, red. 2012. Kodeks karny. Część ogólna. Komentarz. Warszawa: Wolters Kluwer Polska.

Grześkowiak, Alicja, i Krzysztof Wiak, red. 2017. Kodeks karny. Komentarz. Warszawa: Wydawnictwo C.H. Beck.

Konarska-Wrzosek, Violetta, red. 2016. Kodeks karny. Komentarz. Warszawa: Wolters Kluwer Polska.

Królikowski, Michał, i Robert Zawłocki, red. 2010. Kodeks karny. Czesśc ogólna. Tom II. Komentarz. Art. 32-116. Warszawa: Wydawnictwo C.H. Beck.

Mozgawa, Marek, red. 2013. Kodeks karny. Komentarz. Warszawa: Wolters Kluwer Polska.

Renken, John A. 2015. The Penal Law of the Roman Catholic Church. Commentary on Canons 1311-1399 and 1717-1731 and Other Sources of Penal Law. Ottawa: Saint Paul University.

Syryjczyk, Jerzy. 2005. „Powrót do przestępstwa w ujęciu prawa kanonicznego.” Prawo Kanoniczne 48, nr 3-4:151-74.

Syryjczyk, Jerzy. 2008. Sankcje w Kościele. Część ogólna. Komentarz. Warszawa: Wydawnictwo UKSW. 
Wójcik, Walenty, Józef Krukowski, i Florian Lempa. 1987. Komentarz Prawa Kanonicznego z 1983 r. Księga V. Dobra doczesne Kościoła. Księga VI. Sankcje $w$ Kościele. T. 4. Lublin: Redakcja Wydawnictw KUL.

Zoll, Andrzej, red. 2012. Kodeks karny. Część ogólna. Tom I. Komentarz do art. 1116 k.k. Warszawa: Wolters Kluwer Polska.

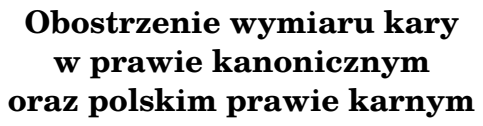

Streszczenie

Ustawodawca kościelny w kan. 1326 § 1 i 2 KPK/83 zawarł okoliczności, które wprawdzie fakultatywnie, ale jednak mogą skutkować surowszym ukaraniem przestępcy. Uregulowania, przewidujące obostrzenie wymiaru kary przewidział również ustawodawca świecki w art. $64 \S 1$ i 2 , art. $65 \S 1$, art. 57 a $\S 1$ i 2 oraz art. $91 \S 1,2$ i 3 Kodeksu karnego. Systemy te nie funkcjonują jednak w próżni. Odnoszą się do konkretnych podmiotów, które są jednocześnie wiernymi Kościoła katolickiego i obywatelami Rzeczypospolitej Polskiej. Niniejszy artykuł ma na celu scharakteryzowanie instytucji obostrzających wymiar kary oraz wskazanie podobieństw i różnic pomiędzy tymi systemami. Prawo kanoniczne i świeckie zawierają systematyczne uregulowania podobne dla nich obu (jak ma to miejsce w przypadku recydywy), jak i je różniące, których jest więcej. Głównym powodem takiego stanu rzeczy jest to, że prawo karne jest prawem o wysokim stopniu abstrakcji, bowiem jest skierowane do wszystkich obywateli Rzeczypospolitej Polskiej, a także osób przebywających na jej terenie. Jego celem jest ukaranie sprawcy w sposób zgodny z oczekiwaniami społeczeństwa oraz prewencja generalna i ogólna. W przypadku prawa kanonicznego odnosi się ono do konkretnych podmiotów będących wiernymi Kościoła katolickiego. Ponadto kieruje się ono zasadą miłosierdzia kościelnego wymiaru kary zawartą w kan. 1349 KPK/83.

Słowa kluczowe: kara; obostrzenie; prawo karne; przestępstwo

\section{Aggravation of Penalties under Canon Law and Polish Criminal Law}

\section{Sum m a ry}

Canon $1326 \S 1$ and 2 CIC/83 provides for circumstances that are optional but can result in a harsher punishment of the offender. Regulations which provide for the aggravation of penalties were also incorporated in Article $64 \S 1$ and 2, Article $65 \S 1$, Article 57a $\S 1$ and 2, and Article $91 \S 1,2$ and 3 of the Penal Code. Both of these systems, however, do not exist in a vacuum. They refer to specific individuals who are simultaneously the faithful of the Catholic Church but also Polish citizens. The presented article is intended to characterize institutions that aggravate penalties and 
to demonstrate the similarities and differences between the two systems. Therefore, the systems of canon law and civil law contain systematic regulations that are both similar (as in the case of reoffending) and different, the latter being more numerous. The main reason for this is that criminal law is highly abstract law because it addresses all Polish citizens as well as individuals staying on the Polish territory. The regulations are designed to punish the perpetrator in a manner consistent with the expectations of the public as well as to serve preventive and educational objectives that the penalty is to achieve with regard to the offender, and the need to develop legal awareness in society. In contrast, canon law addresses specific entities that are the faithful of the Catholic Church. In addition, it is guided by the principle of clemency of church punishment contained in canon 1349 CIC/83.

Key words: penalty; aggravation; criminal law; crime

Information about Author: AGnieszKa SmoluchowskA, J.C.L. - Ph.D. student, Department of Public and Constitutional Church Law, Institute of Canon Law, Faculty of Law, Canon Law and Administration at the John Paul II Catholic University of Lublin; Al. Racławickie 14, 20-950 Lublin, Poland; e-mail: agnisia5@op.pl; https://orcid.org/0000-0003-0540-1439 